\title{
Katja Seutu
}

\section{Näkökulmia runouden realismiin ja sen tutkimiseen - metonyymisyys ja roolirunon laji}

Realismia ja toden tunnun efektin tuottamisen keinoja ei ole juurikaan tutkittu runouden lajikontekstissa. Niinpä asiasta kiinnostunut kohtaa koko joukon ratkaisemattomia metodisia ongelmia ja teoreettisia aukkoja. Johanna Venhon runo "(arki)" (Yhtä jublaa, 2006) herättää runouden realismin kannalta tärkeitä kysymyksiä.

(arki)

1

Se virta joka sillan alla velloo, roiskii ja imaista koettaa on arki, oi arki, natiseva arkki, pyörre ja sinfonia: palanut puuro ja myrsky tiskialtaassa, [- - ]

(Venho, 2006)

Runon otsikon sulkuihin asetettu "arki" edustaa minulle kysymystä, millaisia keinoja runoudesta löytyy sellaisten tekstuaalisten efektien tuottamiseksi, jotka luovat vaikutelman tekstin yhteydestä ulkoisen todellisuuden jokapäiväisyyteen. Entä miten arkisuus "istuu" runouden lajihistoriaan ja niihin konventionaalisiin arvottamisen ja lukemisen tapoihin, jotka seuraavat laahuksena jokaista runoa ja sen tulkintaprosessia? Runon säkeessä "oi arki, natiseva arkki" arkea puhutellaan apostrofisen ylevästi interjektiota "oi" unohtamatta. Viestiikö runo siitä, että puhuttelemalla ylevästi arkea, itsessään kaiken ylevän vastaista ilmiötä, runo jo kääntää ympäri perinteisesti runouteen liitettyjä ylevyyden ja pyhyyden konnotaatioita?

Tarkastelen tässä kirjoituksessa runouden realismia tekstin metonyymisen rakenteen ja roolirunon lajin näkökulmista, sillä ne ilmentävät mielestäni selkeimmin tiettyjen tekstuaalisten, tekstin ja tekstinulkoisen todellisuuden rajaa murtavien efektien muotoutumista ja toimintaa. ${ }^{1}$ Viittaan metonyymisyydellä osien ja kokonaisuuden suhteen varassa rakentuvaan periaatteeseen ja olen kiinnostunut juuri siitä, miten runossa ilmaistut yksityiskohdat toimivat yhteistyössä implisiittisten merkityskokonaisuuksien kanssa. Roolirunon tarkastelu tarjoaa näkökulmia suomalaisessa lyriikantut- 
kimuksessa lähes koskemattomaan runouden alalajiin, jolle ominaisten tekstuaalisten efektien toimintaa kutsun roolirunon retoriseksi rakenteeksi.

\section{Runouden realismin tutkimuksesta}

Realismia koskevat kysymykset eivät ole kuuluneet runouden tutkimukseen siinä määrin kuin proosan tutkimukseen. Runouden lajihistoriasta ei löydy esimerkiksi 1800-luvun realismia vastaavaa ilmiötä, joka olisi kirvoittanut runouden ja realismin suhdetta eri aspekteista avaavia tutkimuksia. Modernistiset, runon autonomiaa korostavat kirjallisuuskäsitykset ja -ismit ovat sysänneet realismia runoudentutkimuksen reuna-alueille. Tämä johtuu ennen kaikkea siitä, että ne keskittivät huomion runouden kieleen, jonka nimenomaiseksi tehtäväksi tuli luoda oma maailma, näyttää asioita uudenlaisista näkökulmista sekä myös vieraannuttaa arkikielestä ja totunnaisesta ajattelusta (vrt. Hökkä 2000, 16-17; Baschmakoff 2000, 235-237). Kun runoon alettiin suhtautua "minänmaailmana", omana universumina, se haluttiin vapauttaa muun muassa suhteesta tekstinulkoiseen todellisuuteen (vrt. Anhava 2002, 393-395), mikä liikutti modernistista runoutta poispäin realismin kysymyksenasetteluista. ${ }^{2}$

Runouden realismin tutkimuksen suurin käytännön ongelma on teorian ja tutkimuksen vähyys. Runouden realismia tutkivan on pääosin luettava proosan realismia koskevaa tutkimusta ja sovellettava ideoita toisen lajin tutkimukseen. Esimerkiksi Lilian R. Furstin tutkimus (1995) osoittaa, että proosan realismin tutkimuksesta löytyy välineistöä runouden realismin tutkimukseen. Furstin esittämät muun muassa lukijan positiota ja merkitystä koskevat kysymykset osoittavat, että proosan ja runouden realismin tutkimukset jakavat yhteisiä kiinnostuksen kohteita. Niin ikään Dorrit Cohnin (2006) tutkimukseen sisältyy runouden realismin kannalta kiinnostavia kysymyksenasetteluja. Erityisesti hänen näkemyksensä sisäisestä monologista ovat hedelmällisiä suhteessa roolirunon lajille ominaiseen monologimuotoiseen, yhden puhujan hallitsemaan puhetilanteeseen.

Roland Barthesin klassinen essee "Toden tuntu” (1993) on sen sijaan esimerkki proosan tutkimuksen soveltamisen vaikeuksista. Vaikka hyödynnän esseessäni Barthesin kirjoituksesta lainattua toden tunnun (l'effet de réel) käsitettä puhuessani tekstuaalisista toden tuntua synnyttävistä efekteistä, eivät Barthesin esseessään esittämät ideat ole aivan ongelmattomia runoudentutkimuksen näkökulmasta. Esseen keskeinen ajatushan on, että näennäisen merkityksettömät yksityiskohdat synnyttävät proosassa toden tunnun. Runon tiivis ilmaisu ja lyhyt muoto, jonka puitteissa jokaisen yksityiskohdan ajatellaan merkityksellistyvän, ei salli proosan tavoin "ylimääräisten" yksityiskohtien runsautta. Tämä käy ilmi esimerkiksi Arvo Turtiaisen runosta ”Ja minä näin" (Tie pilven alta, 1939). 


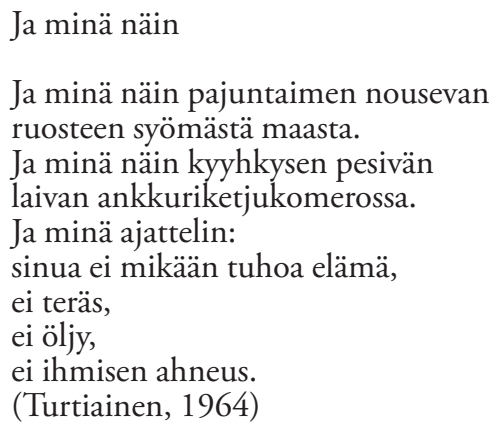

Vaikka Turtiaisen runon kielellisillä elementeillä on kuvaileviakin funktioita, "ruosteen syömä maa", "ankkuriketjukomero", runossa ei ole yhtän merkityksetöntä, siis tematisoitumatonta, elementtiä. ”Ja minä näin” on esimerkki siitä, että muutaman poeettisen, Turtiaisen runon tapauksessa kuvallisen, elementin toiminta riittää synnyttämään runon lyhyessä ja kompaktissa kokonaisuudessa tekstuaalisia efektejä, jotka aktivoivat runoon ulkoisen todellisuuden viitekehyksen. Toisin sanoen se, että "todellisuuden kategoria" tulee runossa merkityksi (vrt. Barthes 1993, 107), toteutuu runossa järjestelmällisesti yksittäisten, runon kokonaisuudessa merkityksellistyvien poeettisten elementtien varassa. Arvo Turtiaisen runon tapauksessa on mielenkiintoista, että runon yhteys ulkoiseen todellisuuteen aktivoituu, kun symbolinen kuvasto toimii yhteistyössä konkreettisen, "aineellisen" kuvaston kanssa: pajuntaimi, uusi elämä, nousee ruosteen syömästä maasta, ja kyyhkynen, rauhan symboli, pesii keskellä ihmisten arkea, laivan ankkuriketjukomerossa.

Arvo Turtiaisen runon kuvallisten elementtien yhteistyö vahvistaa ajatustani siitä, että realistisen näkökulman relevanssi ratkeaa runon tai runoteoksen kokonaisuutta vasten. Otan vastaesimerkiksi Tomi Kontion runon "(Kontula)" (Taivaan latvassa, 1998), joka herättää kysymyksen, kuinka relevantti runossa aktivoituva ulkoinen, itähelsinkiläisen lähiön viitekehys on koko runon kannalta.

\section{(Kontula)}

Tähdet putoavat taivaan harteille kuin hilse. Kävelen Ostostiellä ja panen taskuuni palasen Linnunrataa. Olet lähellä, lähempänä kuin koskaan. Olen ajatellut, että tällaisena yönä, kun kuljen kirjoittamani maiseman lävitse ja Siriuksen ulvonta on yhtä äänekästä kuin kapakan eteen unohdetun piskin vaikerrus, että tällaisena yönä voisin ehkä sanoa jotain mitä olet halunnut. Kuulla. (Kontio, 1998)

Vaikka paikanilmaukset Kontula ja Ostostie kytkevät runon esittämän paikan itähelsinkiläiseen lähiöön, runoa lukiessa huomataan, että siihen sisältyy nopeita siirtymiä Ostostieltä taivaan avaruuksiin. Konkreettiseen tilaan kutoutuu sekä metalyyrisiä ulot- 
tuvuuksia, "kuljen kirjoittamani maiseman lävitse", että antiikin mytologian aiheistoa, "Siriuksen ulvonta on yhtä äänekästä kuin kapakan eteen unohdetun piskin vaikerrus", jotka kummatkin rikkovat runon otsikon myötä aktivoituvaa viittausta ulkoiseen todellisuuteen. Kontion runo kiinnittääkin huomiota kaunokirjalliselle tekstille ominaiseen "ei-referentiaalisuuteen", jota Dorrit Cohn (2006, 20-28 ) käsittelee tutkimuksessaan fiktiivisen proosan ominaisuutena. "(Kontula)" ei toisin sanoen tietyistä paikanilmauksistaan huolimatta viittaa yksinomaan ulkoiseen todelliseen maailmaan vaan kyse on Cohnin (mt., 25-26) ilmaisua käyttäen pikemminkin siitä, että runon "ulkoiset viittaukset [- - ] ovat ikään kuin fiktiivisen maailman tartuttamia". Paikanilmaukset Kontula ja Ostostie ovat Tomi Kontion runossa yhtäältä toden tunnun efektin synnyttäviä komponentteja. Toisaalta ne toimivat ennen kaikkea ponnahduslautana, joka sinkoaa lukijan sisälle fiktiivisen tekstin omiin lainalaisuuksiin. Realistinen näkökulma ei vaikuta yksistään riittävältä lähtökohdalta "(Kontulan)", eikä liioin teoksen Taivaan latvassa kokonaisuutta vasten. ${ }^{3}$

Runouden realismi, kuten ylipäätään kaunokirjallisuuden realismi, on kiehtova alue juuri siksi, että realismiin kytkeytyy aina tietynlainen harhan aspekti, joka nähdään Tomi Kontionkin runossa. Vaikka runossa tuotettaisiin erilaisin kirjallisin keinoin tekstuaalisia efektejä, jotka synnyttävät vaikutelman tekstin yhteydestä ulkoiseen todellisuuteen, ei tällainen tarttumapinta vielä takaa, että runon lukeminen on relevanttia juuri tästä aspektista käsin. Tuore esimerkki tästä on Panu Tuomen Einsteinin viimeiset sanat. Dialogi sairasvuoteen äärellä (2008). Vaikka alaotsikko synnyttää yhdessä pääotsikon kanssa assosiaation ihmisen viimeisistä hetkistä kuolinvuoteella, on realismin näkökulmasta huomiota herättävää, että teos ei alaotsikkoa lukuun ottamatta esitä varsinaisesti kuolinvuoteella olemista ja sairautta. Erityisesti tämä nousee esiin Einsteinin kanssa dialogia käyvän, sairaanhoitajan rooliin asetetun Albertan näkökulmasta. Vaikka fiktiivisen hoitajan nimi on sama kuin Einsteinia todellisuudessakin hoitaneen henkilön, häntä ei tunnista sairaanhoitajaksi käytöksen, tekojen eikä juuri puheenkaan perusteella; empaattinen hoivaaminen, joka näkyisi sairasvuoteen äärellä myös tekoina, puuttuu teoksesta.

\section{Miten yksityisestä tulee yhteistä? \\ Metonyyminen rakenneratkaisu ja psykofyysisen tilan esittäminen}

Tarkastelen seuraavaksi tekstin metonyymista rakentumista ja sen synnyttämiä tekstuaalisia efektejä. Viittaan metonyymisyydellä yhtäältä metonymiaan, kielikuvaan, joka rakentuu osan ja kokonaisuuden välisen suhteen varassa ja toisaalta kielikuvaa laajempaan teoskokonaisuutta tai runon kokonaisuutta hahmottavaan rakenneratkaisuun (vrt. Haapala 2003, 145). Metonyyminen rakenne voi toimia tekstin sisäistä koherenssia säätelevänä elementtinä, tai aivan päinvastaisesti (Emig 1995, 69-79; 
Haapala mt., 148-153). Klassinen esimerkki tekstin sisäistä koherenssia säätelevästä metonyymisen periaatteen toiminnasta on Marcel Proustin Kadonnutta aikaa etsimässä -teoksen madeleine-leivos, joka palauttaa Marcelin mieleen menneiden aistimusten ja kokemusten kirjon. ${ }^{4}$ Vesa Haapala on tutkinut metonyymisia rakenneratkaisuja ennen kaikkea intertekstuaalisina viittaussuhteina: intertekstuaalinen metonyymisyys ylittää yksittäisen tekstin rajat ja saa monenlaisia ilmentymiä. Kyse voi olla esimerkiksi siitä, että historiallinen viitekehys tulee osaksi tietyn tekstin merkitystasoa (mt., 152), siitä, että eri lähteistä peräisin olevat diskurssit kohtaavat toisensa yksittäisessä tekstissä (mt., 158-162) tai siitä, että biografiset viittaukset luovat tekstiin autobiografisen tason (mt., 163). Metonyymisyys voidaan niin ikään ymmärtää tekstin lukijaan suuntaamaksi lukuohjeeksi (mt., 153 ja Haapalan mainitsemat lähteet); lukija voi halutessaan tarttua tekstistä tarjoutuviin vihjeisiin ja hyödyntää niitä luennassa ja tulkinnassa.

Metonyymisyyden anti runouden realismin tutkimukselle perustuu esimerkeissäni metonymialle tyypillisen pars pro toto (osa edustaa kokonaisuutta) -rakenteen toimintaan, johon viitataan tutkimuksissa niin ikään käsitteellä synekdokee. Osa-kokonaisuus -suhteessa ei ole kyse esimerkeissäni yksinomaan metonymian perusmärititelmästä rajattuna kielikuvana, joka toteuttaa läheisyyden periaatteelle perustuvan korvauksen, esimerkiksi "teräs välähti” vs "veitsi välähti” (vrt. Haapala 2003, 148). Se on ymmärrettävä laajemmin metonyymisyytenä, jossa osa edustaa kokonaisuutta runokokonaisuuden tulkinnan kannalta merkittävällä tavalla. Otan metonyymisesta rakenteesta esimerkiksi Lucien Strykin runon ”Desk" (Collected Poems 1953-1983, 1984).
Desk
Dictionary
Typewriter
Paper
Seven pipes
Ashtray
Three pens
Two elbows
(Stryk, 1998)

Metonyymisyys toteutuu runossa rakenteellisena osien ja kokonaisuuden suhteena. Lucien Strykin runoa tarkasteltaessa huomataan, että siihen syntyy osa-kokonaisuus -suhteen keinoin tila ja henkilö. Sanakirja, kirjoituskone, paperi, piiput, tuhkakuppi ja kynät edustavat otsikon kirjoituspöytää, työnteon tilaa. Kaksi kyynärpäätä edustavat ihmistä. Metonyyminen periaate toimii runossa kahdella tapaa: osista rakentuu koko- 
naisuuksia, ja metonyyminen rakenneratkaisu ohjaa luennan ja tulkinnan suunnaksi horisontaalisen, asiasta toiseen jatkumollisesti etenevän lineaarisen suunnan. Ensin syntyy tila, ja tähän tilaan tuodaan vasta runon lopuksi henkilö, mikä kohdistaa huomion pääasiallisesti juuri häneen. ${ }^{5}$

Metonyyminen kuva rakentuu runossa toisaalta yksityiskohdista ja pyrkii tarkkuuteen. Toisaalta paljon jää sanomatta, sillä kokonaisuus voi rakentua vain rajatusta määrästä yksityiskohtia. Metonyyminen rakenne, se, että metonyyminen kuva on tarkka ja jättää toisaalta paljon ilmaisematta, on runoudelle ominaista tiivistä ilmaisua ajatellen erittäin taloudellinen runoilmaisun keino. Metonyymisessa osa-kokonaisuus -suhteessa on merkityksellistä ilmaistun suhde siihen, mikä jää ilmaisematta (vrt. Launonen 1984, 201). ${ }^{6}$ Strykin runossa työnteon tilan ja henkilön suhde jää vaille ilmaisua. Se on kuitenkin runosta tunnistettavissa: sen implisiittinen läsnäolo perustuu kokonaisuutta edustavien yksityiskohtien toimintaan. Ilmaisematon kytkös, työnteon tilan ja henkilön suhde, vaikuttaa runon tulkintaan. Se, mikä jää vaille ilmaisua on tunnistettavissa jakamamme tekstinulkoista todellisuutta koskevan yhteisen tietämyksen perusteella, ja on siis tässä mielessä kulttuurisidonnaista. Toisin sanoen metonyymiselle rakenteelle ominainen asiasta toiseen horisontaalisesti/lineaarisesti etenevä suunta edustuu paitsi tekstin sisäisenä myös tekstin rajat ylittävänä liikkeenä ja aktivoi runoon tekstinulkoisen kehyksen. Tulkintani mukaan Strykin runossa vaille ilmaisua jäävä työnteon tilan ja henkilön suhde avautuu kirjoittajan/kirjailijan työn kognitiiviseksi kuvaukseksi. ${ }^{7}$

Bo Carpelanin runoutta tutkineen Anna Hollstenin mukaan $(2004,45)$ metonymioiden tehtävä on Carpelanin runoissa "näyttää maailma mahdollisimman tarkasti 'sellaisena kuin se on'”. Hollstenin havainto on toiminut itselleni virikkeenä sen ymmärtämiseksi, että metonyymiselle rakenteelle ominainen tarkka, yksityiskohtien varassa rakentuva ilmaisu ja sen suhde ilmaisematta jätettyyn tekee mahdolliseksi paitsi konnotaatiot tekstinulkoiseen todellisuuteen myös vahvan emotionaalisen latauksen syntymisen. Emotionaalinen lataus on hallitsevasti läsnä seuraavassa Bo Carpelanin runossa $\left(73\right.$ dikter, 1966). ${ }^{8}$

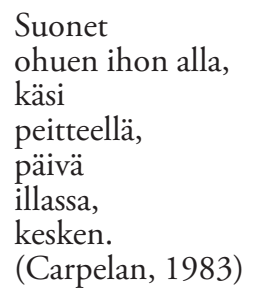

Käden suonet, ohut iho, sängyssä makaava hahmo ja päivä illassa rakentavat kuolevan henkilön runoon metonyymisesti. Runon niukkuus ja sana sanalta etenevä rytmi luovat vahvan emotionaalisen latauksen. Pidän metonyymisen rakenneperiaatteen merkit- 
tävimpänä ominaisuutena sitä, että se on runon vahva keino esittää jotakin havaintoa, tunnetilaa tai psykofyysistä kokemusta mahdollisimman todentuntuisesti ja intiimisti. Emotionaalinen lataus perustuu juuri siihen, että runon esittämä tunne tai kokemus välittyy metonyymisen rakenteen keinoin mahdollisimman tarkasti. Merkillepantavaa on, että toden tunnun efektin synnyttävä metonyyminen runon rakentuminen tekee tekstin ilmaisemasta kokemuksesta ja tilasta yleisesti tunnistettavan. Yksityisen kokemuksen muotoutumista yhteiseksi voisi kuvata Panu Tuomen $(2006,65)$ eri yhteydessä käyttämiä sanoja lainaten siten, että Carpelanin runo paljastaa "läpikuultavuudessaan [- - k kokemuksen alastomimmillaan, jolloin lukija tunnistaa sen omakseen".

\section{Roolirunon retorinen rakenne}

Runon suhde tekstinulkoiseen todellisuuteen tuntuu ilmenevän monissa runoissa juuri yksityisen ja yleisen/yhteisen murtumakohtana, jossa yksityinen kokemus kohtaa yleisinhimillisen kokemuksen. Niin ikään yksityisen ja yhteisen rajapintaa murtava roolirunon laji tarjoaa metonyymisyyden ohella antoisan runon realismin tutkimusalustan. ${ }^{9}$ Eva Lilja (1988, 31-33), joka on pohtinut 1960-luvun ruotsalaisen runouden realismia, kytkee juuri lajilähtöisen menetelmän, runomuotokuvat ja muun henkilökuvaukseen ("mänskoskildring") pyrkivän runouden, osaksi runouden realismin tutkimusta. ${ }^{10}$

Draamallista monologia, jolla nimikkeellä rooliruno tunnetaan kansainvälisessä tutkimustraditiossa, pidetään yhtenä viktoriaanisen ajan merkittävimmistä poeettisista innovaatioista, jonka lajitaustat ovat moninaiset (Slinn 2002, 80-81) ja jonka katsotaan kehittyneen erityisen pitkälle Robert Browningin (1812-1889) runoudessa (Porter 1993, 9; Loehndorf 1997, 149). ${ }^{11}$ Viktoriaanisella draamallisella monologilla on ollut sittemmin suuri vaikutus angloamerikkalaiseen modernistiseen runouteen erityisesti Ezra Poundin ja T. S. Eliotin runouden välityksellä. ${ }^{12}$ Suomalaiseen kirjallisuudentutkimukseen vakiintunut roolirunon käsite juontaa juurensa saksalaisesta käsitteestä das Rollengedicht (vrt. Koskimies 1962, 151). Roolirunoja on kirjoitettu kaikissa kirjallisuushistoriamme vaiheissa; varhaisia roolirunoja löytyy muun muassa Eino Leinon Helkavirsistä. Lajin kultakauden muodostaa vasemmistolaisen kirjailijaryhmä Kiilan piirissä pääosin ajanjaksona 1930-60 kirjoitettu roolirunous, joka on puolestaan saanut vaikutteita Elmer Diktoniukselta. Kiilalaisella kantaaottavalla roolirunoudella on sittemmin ollut suuri vaikutus lajia 1950- ja 60-lukujen vaihteessa merkittävällä tavalla kehittäneen Maila Pylkkösen (1931-1986) runouteen sekä myöhempien vuosikymmenten roolirunouteen. ${ }^{13}$

Roolirunon lajille on ominaista runon puhujan yksilöityminen ja runon puhetilanteen korostuminen. Puhuja ilmaisee kokemuksiaan, tunteitaan ja ajatuksiaan, jotka ovat usein sidoksissa tietyn fiktiivisen tilanteen ajallispaikalliseen kehykseen. Rooliruno voi esittää puhujan tiettyyn elämäntilanteeseen kulminoituvaa sisäistä kriisikokemus- 
ta. Otsikko on roolirunon tärkeä lajitunnus, sillä se saattaa antaa vihjeitä siitä, mikä tai millainen runon puhuja on tai millaisesta positiosta puhuja itseään ilmaisee. Roolirunojen puhujia on monenlaisia. Usein puhujat ovat myyttien ja satujen hahmoja tai henkilöitä, joilla on historiallinen esikuva. Puhujat voivat olla niin ikään eläimiä, elottomia asioita tai olioita, tai sitten "tavallisiksi" luonnehdittavia puhujia, jotka jakavat lukijan kanssa yhteistä, enemmän tai vähemmän lähietäisyydeltä ymmärrettävää todellisuutta. ${ }^{14}$ Roolirunon merkittävin geneerinen ominaispiirre on sen hierarkkinen rakenne. Esitän lyhyesti Riina Katajavuoren runoa "Beslan" (Kerttu ja Hannu, 2007) esimerkkinäni käyttäen, millaisin perustein roolirunon hierarkkinen rakenne on erityisen kiinnostava juuri runouden realismin näkökulmasta.

Dzerassa Gappojevalle (9.1.1998-3.9.2004)

Beslan

Tuo vettä,

on jano.

Tuo kyynelvettä myös,

pirskota suolavettä tiesulun molemmin puolin.

Tuo helakka kukka.

Tuo Coca-Colaa,

on jano.

Olen tavallinen lellivauva,

aamulla näytin sinulle kieltä.

Kiristä lettinauha,

tukka sojottaa.

Asettele röyhelökaulus,

tänään se ei saa repsottaa.

Olen vasikka joka vedettiin sorkista ulos,

sitä läpituloa sinä et unohda ikinä.

Olit taintua kun potkaisin sinua.

Limaisena ja verisenä

putosin sinusta pois.

Tuo vettä,

tuo helakka kukka,

tuo Coca-Colaa.

Olen sinun lapsesi,

olen kukkatukkainen röyhelöpuserotyttö.

Olen ikuisesti lapsi.

Mutta tiedätkö äiti,

niin ovat ikuisesti lapsia kaikkien muidenkin äitien lapset.

Aikuisinakin, ikuisesti lapsia äideilleen. 
Kokeile punaista graniittia kädelläsi.

Onko se kylmää?

Aurinko on paahtanut koko päivän.

Graniitin täytyy olla jo lämmintä.

Lämmintä ja sileää se on.

Tuot vettä, tuot kukan, tuot Coca-Colaa.

Tulee kirkas yö.

Olen sinimekko kultatukka,

minulla on ilmapalloja käsissäni.

Jumppasalin katossa oli tähtiä.

(Katajavuori, 2007)

"Beslan" on tulkittavissa roolirunoksi, jonka puhuja on itseään yksikön ensimmäisessä persoonassa ilmaiseva pieni tyttö. Puhuja yksilöityy luonnehtimalla ulkomuotoaan, "olen sinimekko kultatukka", ja tuntemuksiaan, "on jano". Otsikko antaa runolle traagisen ajallispaikallisen kehyksen: Beslan viittaa syyskuussa 2004 sattuneeseen venäläiseen koulukaappaukseen ja ilmaisee tytön olevan yksi kaappauksen uhreista. Roolirunon lajille ominainen hierarkkinen rakenne muotoutuu kahden tekstuaalisen tason vaikutussuhteena. Puhujataso, jota edustaa "Beslanissa" pieni tyttö runon puhujana, on roolirunossa eksplisiittisesti havaittavissa ja alisteinen hierarkkisesti ylemmälle tasolle, jota nimitän retoriseksi tasoksi (vrt. Haapala 2005, 79-83). Retorinen taso vastaa runon ideologisesta ja temaattisesta kokonaisuudesta. Peter Hühn $(2005,152)$ nimittää retorista tasoa vastaavaa tahoa komposition subjektiksi ("subject of composition"). Käsite on havainnollinen, sillä Hühn viittaa sillä tahoon, joka vaikuttaa siihen, millaisena runon puhujan asema näyttäytyy runossa ja miten se tulee esiin.

"Beslan" on roolirunon hierarkkisen jäsennyksen kannalta kiinnostava, sillä retorinen taso on siinä läsnä poikkeuksellisen voimakkaasti. ${ }^{15}$ Se eksplikoituu ensimmäisen kerran runon omistuksessa ja otsikossa. Sen runon temaattista ja ideologista kokonaisuutta säätelevä vaikutus näkyy ensinnäkin siten, että pienen tytön monologiin sekoittuu ikään kuin vieraita sanoja, "tiesulku” ja "kyynelvesi”, jotka virittävät yhdessä otsikon kanssa koulukaappauksen viitekehyksen. Toisaalta retorisen tason toiminta näkyy monitulkintaisessa äidille suunnatussa repliikissä "niin ovat ikuisesti lapsia kaikkien muidenkin äitien lapset. / Aikuisinakin, ikuisesti lapsia äideilleen." Vaikka repliikki on tytön ilmaisema, se sisältää vieraan, aikuisemman näkökulman, joka implikoi tiedon tragediasta. Runo virittää tulkinnan, että kaappauksessa kuolleet lapset jäivät ikuisesti lapsiksi. Tytön monologiin hienovaraisesti limittyvä lapsen näkökulmaa laajempi, tyttöä kuvaileva ja kokonaistilanteen tiedostava näkökulma voidaan aistia koko runosta. Merkittävin retorisen tason toimintaa ilmentävä kohta on runon viimeinen, omaksi säejaksoksi erotettu säe "Jumppasalin katossa oli tähtiä", jossa imperfektimuotoisen 
verbin aiheuttama asennonvaihdos ilmaisee tytön monologin ja olemassaolon päättyneen.

Rooliruno on lajina kantaaottava; roolirunot ilmaisevat usein muun muassa yhteiskunnallisesti kriittistä asennetta. Usein ääni annetaan roolirunoissa fiktiivisille henkilöille, joiden kokemukset tai tilanne kuvastavat vähemmistöjen, esimerkiksi sairaiden ja vanhusten, todellisuutta. Kantaaottavuus toteutuu juuri puhujatason ja retorisen tason yhteistyönä, retorisina efekteinä, jotka murtavat puhujan sisäisen todellisuuden ja yhteisen todellisuuden rajapintaa. Tähän tarvitaan kuitenkin myös lukijaa, jolla on aktiivinen paikka roolirunon kehyksessä. Sen lisäksi, että retorinen taso on kielellisin ja poeettisin keinoin rakentuva semanttinen tai ideologinen taso, se on myös tulkinnallinen hypoteesi. Sen perusta on toisin sanoen teoksen poetiikassa, mutta se tarvitsee tullakseen nähdyksi myös analysoivan ja tulkitsevan vastaanottajan. Runon lukija kuuntelee roolirunon puhujan monologia ja tulkitsee tämän fiktiivistä puhetta. Lukija tulee roolirunoa lukiessaan varsin helposti tietoiseksi runossa vaikuttavasta hierarkkisesta rakenteesta: siitä, että puhujan monologi on asetettu runon etualalle jostakin tietystä syystä. Roolirunon laji tarjoaa mielenkiintoisen ja konkreettisen lähtökohdan runon realistisuuden ja sen keinojen tutkimiseksi, koska roolirunossa toden tunnun efekti perustuu lajille ominaisen hierarkkisen rakenteen toimintaan, jossa myös runon lukijalla on paikkansa.

\section{Viitteet}

${ }^{1}$ Runouden realismin kannalta kiinnostava kysymys olisi myös erilaisten runouden traditioiden suhde todellisuuteen ja sen esittämiseen. Bowran (1966) tutkimus tarjoaa lähtökohtia visionäärisen runouden tarkasteluun. Visionäärisen runouden, jonka tunnetuin edustaja on William Blake, suomalainen traditio on ollut niukasti esillä. Sitä voitaisiin lähestyä tutkimalla muun muassa Mirkka Rekolan ja Risto Ahdin runoutta.

${ }^{2}$ En voi paneutua tässä kirjoituksessa asiaan tarkemmin. Ks. aiheesta Seutu, tulossa.

${ }^{3}$ On toki sellaisiakin runoja, joissa fiktiivinen maailma ja tekstinulkoinen todellisuus rakentavat tiiviin kudoksen. Sanna-Mari Pirkolan valitettavan vähän huomiota saaneessa esikoisrunoteoksessa Ylivieska (2006) paikkaisuus palvelee toden tunnun efektiä. Ylivieskasta otetut kuvat ja Ylivieska-aiheiset runot kuvittavat yhdessä sekä maantieteellistä Ylivieskanimistä paikkaa että teoksen Ylivieskaan kytkeytyvää mentaalista maisemaa ja tilaa.

${ }^{4}$ Ks. myös Paavo Haavikon Talvipalatsin maisemametonymiasta Kaunonen 2001, 41-52.

Kaunosen mukaan Haavikon teoksen "maisemat muodostavat yhdessä metonyymisen merkityskokonaisuuden", joka toimii ikään kuin purettavana ja uudelleen koottavana lavasteena runosta toiseen.

${ }^{5}$ Gérard Genette $(1982,119)$ luonnehtii metonymian suuntaa horisontaaliseksi ja metaforan vertikaaliseksi: "In the metaphor-metonymy couple, it is tempting to see the opposition between the spirit of religious transcendence and the down-to-earth spirit, dedicated to the immanence of the here-below. Metonymy and Metaphor are the two sisters of the Gospel: 
Martha, the active one, the housewife busying herself, walking up and down, duster in hand, from one object to another, and Mary, the contemplative one, who has 'chosen the better part' and will go straight to heaven. Horizontal versus vertical."

${ }^{6}$ Ks. Paavo Haavikon ja Lauri Viidan runouden metonyymisyydestä Launonen 1984, 200202; 1988.

${ }^{7}$ Panu Tuomi $(2006,64)$ tulkitsee runon ilmentävän muun muassa kirjallisen työn yksinäisyyttä, mikä on mielestäni niin ikään relevantti tulkinta.

${ }^{8}$ Ådrorna

under den tunna

huden,

handen

vid täcket,

dagen

vid sitt slut,

oavslutad.

(Carpelan, 1966)

${ }^{9}$ Rooliruno ei ole ainoa runon realismin näkökulmasta kiintoisa runouden laji. Aforismin

lajin kantaaottava laatu tulee esiin muun muassa suomalaista aforismia merkittävällä tavalla uudistaneen Mirkka Rekolan aforistiikassa.

${ }^{10}$ Roolirunon ja runomuotokuvan eron määrittelen siten, että rooliruno on monologimuotoinen, yksikön ensimmäisessä persoonassa esitetty runo, kun taas muotokuvaruno on kolmaspersoonainen (ks. Seutu, tulossa).

${ }^{11}$ Viktoriaanisen draamallisen monologin ominaispiirteistä ks. Howe 1996; Loehndorf 1997. Käsitteen historiasta ks. Culler 1975, 366; Rosmarin 1985, 108; Faas 1988, 20.

${ }^{12}$ Ks. tarkemmin esimerkiksi Porter 1993, 10-11; Howe 1996, 66; Loehndorf 1997, 85-88, 116-148; Pearsall 2000, 84-85; Christ 2002, 6.

${ }^{13}$ Ks. tarkemmin Seutu, tulossa. Kirjailijaryhmä Kiilasta tarkemmin myös Sallamaa 1994; Rinne 2006.

${ }^{14}$ Maila Pylkkösen roolirunouden merkitys perustuu juuri ns. tavallisten naispuhujien elämäntilanteen esittämiseen. Suomalaisesta roolirunoudesta, roolirunon lajipiirteistä sekä roolirunon ja draamallisen monologin suhteesta ks. tarkemmin Seutu, tulossa. Uusimmasta suomalaisesta roolirunoudesta ks. Seutu 2007.

${ }^{15}$ Tavallisesti retorinen taso on varsin implisiittinen, vaikka sen vaikutukset voivat olla moninaisia. Valitettavasti en voi tämän esseen puitteissa antaa esimerkkejä useammasta roolirunosta.

\section{Lähteet}

ANHAVA, TUOMAS 2002 / I956: Runon uudistumisesta. Eeva-Liisa Manner: Tämä matka. Tammi 1956. Todenkaltaisuudesta. Kirjoituksia vuosilta 1948-1979. Toim. Helena ja Martti Anhava. Helsinki: Otava. 389-400.

BARTHES, ROLAND I993 / i 968 : Toden tuntu. (L'effet de réel.) Suom. Lea Rojola ja Pirjo Thorel. Tekijän kuolema, Tekstin syntymä. Toim. Lea Rojola. Tampere: Vastapaino. 
BASCHMAKOFF, NATALIA 2000: Venäläisiä futuristeja. Oi runous. Romantiikan ja modernismin runouskäsityksiä. Toim. Tuula Hökkä. Helsinki: SKS. 235-237.

Bowra, с. м. 1966: Poetry \& Politics. The Wiles Lectures given at the Queen's University Belfast 1965. Cambridge: Cambridge University Press.

CARPELAN, BO I966: 73 dikter. Helsingfors: Schildts.

CARPELAN, во I983 (1974): Elämä jota elät. Valitut runot 1946-1983. Suom. Tuomas Anhava. Helsinki: Otava.

Christ, CAROL T. 2002: Introduction: Victorian Poetics. A Companion to Victorian Poetry. Ed. by Richard Cronin et al. New York: Blackwell Publishers Ltd. 1-21.

COHN, DORRIT 2006/I999: Fiktion mieli. (The Distinction of Fiction.) Suom. Paula Korhonen, Markku Lehtimäki, Kai Mikkonen ja Sanna Palomäki. Helsinki: Gaudeamus.

CUller, DWight A. I975: Monodrama and the Dramatic Monologue. PMLA vol. 90, number 3/1975. 366-385.

EMIG, RAINER I995: Modernism in Poetry: Motivations, Structures and Limits. London, New York: Longman.

faAs, EKBert 1988: Retreat into the Mind. Victorian Poetry and the Rise of Psychiatry. Princeton: Princeton University Press.

FURST, Lilian R. I995: All is True. The Claims and Strategies of Realist Fiction. Durham, London: Duke University Press.

GeNeTte, GÉRARD 1982/I972: Figures of Literary Discourse. Transl. by Alan Sheridan. Introduction by Marie-Rose Logan. New York: Columbia University Press.

HAAPAla, vesa 2003: Kutsuja, hyppyjä, tilavaa puhetta. Pentti Saarikosken myöhäistuotannon metonyymisia ratkaisuja. Kuvien kehässä. Tutkielmia kirjallisuudesta, poetiikasta ja retoriikasta. Toim. Vesa Haapala. Tietolipas 191. Helsinki: SKS. 144-182.

HAAPALA, VESA 2005: Kaipaus ja kielto. Edith Södergranin Dikter-kokoelman poetiikkaa. Suomalaisen Kirjallisuuden Seuran toimituksia 1012. Helsinki: SKS.

HOLlsten, ANNA 2004: Ei kattoa, ei seiniä. Näkökulmia Bo Carpelanin kirjallisuuskäsitykseen. Suomalaisen Kirjallisuuden Seuran toimituksia 982. Helsinki: SKS.

howe, elisabeth A. I 996: The Dramatic Monologue. New York: Twayne Publishers. HÜHN, PETER 2005: Plotting the Lyric: Forms of Narration in Poetry. Theory into Poetry. New Approaches to the Lyric. Ed. by Eva Müller-Zettelmann and Margarete Rubik. Amsterdam, New York: Rodopi. 147-172.

нÖKкё, TUULA 2000: Tunteen ja kielen poetiikat. Oi runous. Romantiikan ja modernismin runouskäsityksiä. Toim. Tuula Hökkä. Helsinki: SKS. 11-20.

KaUnOnen, LeEna 200 I: Sanojen palatsi. Puhujan määrittely ja teoskokonaisuuden hahmotus Paavo Haavikon Talvipalatsissa. Suomalaisen Kirjallisuuden Seuran toimituksia 852. Helsinki: SKS.

KatajavUORI, RiINa 2007: Kerttu ja Hannu. Runoja. Helsinki: Tammi. 
коNтіо, томі і 998: Taivaan latvassa. Helsinki: Tammi.

KOSKIMIES, RAFAel 1962/I 937: Yleinen runousoppi. Kolmas painos. Helsinki: Otava. LAUNONEN, HANNU I984: Suomalaisen runon struktuurianalyysia. Tutkimus Jaakko Juteinin, Aleksis Kiven, Otto Mannisen, Eino Leinon, V. A. Koskenniemen, Uuno Kailaan, Kaarlo Sarkian, Tuomas Anhavan, Paavo Haavikon ja Pentti Saarikosken lyriikasta. Helsinki: SKS.

LAUNONEN, HANNU I988: Poeettisen kielen kaksi periaatetta. Lauri Viidan ratkaisuja. Teokset, taustat, tutkijat. KTSV 42. Toim. Jaana Anttila. Helsinki: SKS. 11-37.

LILJA, EVA I988: Nyenkelheten, modernismen och den realistiska poesien. Tidskrift för Litteraturvetenskap. Sjuttonde årgången. 1/1988. 28-43.

LOeHndORf, ESTHER 1997: The Master's Voices. Robert Browning, the Dramatic Monologue, and Modern Poetry. Swiss Studies in English. Tübingen und Basel: Francke Verlag.

pearsall, CORnelia D. J. 2000: The dramatic monologue. The Cambridge Companion to Victorian Poetry. Ed. by Joseph Bristow. Cambridge: Cambridge University Press. 67-88.

PIRKOLA, SANNA-MARI 2006: Ylivieska. Helsinki: Avain.

Porter, Peter I993: Recording Angels and Answering Machines. Proceedings of the British Academy 80. 1991 Lectures and Memoirs. Warton Lecture on English Poetry. Oxford: Oxford University Press. 1-18.

RINNE, MatTI 2006: Kiila 1936-2006. Taidetta ja taistelua. Helsinki: Tammi.

rosmarin, adena 1985: The Power of Genre. Minneapolis: University of Minnesota Press.

SALLAMAA, KARI I994: Kansanrintaman valo. Kirjailijaryhmä Kiilan maailmankatsomus ja esteettinen ohjelma vuosina 1933-1943. Suomalaisen Kirjallisuuden Seuran toimituksia 609. Helsinki: SKS.

SEUTU, KATJA 2007: Lupa puhua. Roolirunous kukoistaa 2000-luvun runoudessa. Parnasso 7/2007. 17-21.

Seutu, Katja (TUlossa): Roolirunon laji Maila Pylkkösen teoksessa Arvo. Vanhaäiti puhuu runonsa. Väitöskirjan käsikirjoitus.

SLINN, Warwick E. 2002: Dramatic Monologue. A Companion to Victorian Poetry. Ed. by Richard Cronin et al. New York: Blackwell Publishers Ltd. 80-98.

stryk, Lucien 1998: And Still Birds Sing. New \& Collected Poems. Athens, Ohio: Swallow Press, Ohio University Press.

tuomi, panu 2006: Poeettinen korrektius. Esseitä ja muita kirjoituksia. Tampere: Sanasato.

TUOMI, PANU 2008: Einsteinin viimeiset sanat. Dialogi sairasvuoteen äärellä. Helsinki: WSOY.

turtiainen, ARVo i964: Tie pilven alta. Runoja 1934-1964. Helsinki: Tammi. venho, JOHANna 2006: Yhtä juhlaa. Runoelma. Helsinki: WSOY. 